\section{Overseeding Strategies for Converting Golf Course Fairways to Creeping Bentgrass}

\author{
Zachary J. Reicher and Glenn A. Hardebeck ${ }^{\mathbf{1}}$ \\ Department of Agronomy, Purdue University, West Lafayette, IN 47907-1150
}

Additional index words. annual bluegrass, Poa annua sp., Agrostis palustris, perennial ryegrass, Lolium perenne

\begin{abstract}
Converting cool-season golf course fairways to creeping bentgrass (Agrostis palustris Huds.) is desirable because it affords excellent playability, enhanced recuperative potential, and enhanced disease tolerance compared to annual bluegrass (Poa annua sp. Timm.) or perennial ryegrass (Lolium perenne), which are common species in fairways. However, converting current golf course fairways to creeping bentgrass with nonselective herbicides is problematic because it disrupts play and decreases revenue, as fairways must be closed for an extended period of time. The objective of our study was to quantify the effect of trinexapac-ethyl (TE), overseeding date, and overseeding rate on the success on the gradual conversion of cool-season fairways to creeping bentgrass over 3 years. 'Penneagle' creeping bentgrass was overseeded at 0,49 , or $98 \mathrm{~kg} \cdot \mathrm{ha}^{-1}$ in fall, spring, or fall+spring after aerification, and application of TE at $0.0,0.2$, or $0.4 \mathrm{~kg} \cdot \mathrm{ha}^{-1}$. Gradual conversion to creeping bentgrass was effective, on perennial ryegrass fairways, with up to $36 \%$ cover of creeping bentgrass after 3 years of overseeding. However, only a maximum of $3 \%$ creeping bentgrass cover was obtained after the third year of overseeding into primarily annual bluegrass fairways. Fall overseeding with bentgrass at 49 or $98 \mathrm{~kg} \cdot \mathrm{ha}^{-1}$ was equally effective and additional spring overseeding did not improve establishment. Applications of TE prior to overseeding did not enhance the conversion. Chemical name used: 4-cyclopropyl-a-hydroxy-methylene-3,5-dioxo-cyclohexanecarboxylic acid ethyl ester (trinexapac-ethyl).
\end{abstract}

Creeping bentgrass is becoming more popular for golf course fairways because of improved cultivars, management tools, and equipment. When constructing a new golf course, creeping bentgrass can be established with little difficulty. However, converting existing fairways to creeping bentgrass can be problematic. Conversion of established fairways is typically done through an application of a nonselective herbicide, aggressive aerification, and vertical mowing to prepare a seedbed, and then drop-seeding or slit seeding with creeping bentgrass. With this technique, fairways must be closed for 8 weeks or more, resulting in lost revenue and inconvenience for golfers. Furthermore, if this process is initiated in midAugust when germination and establishment of creeping bentgrass is favored, the loss of revenue is exaggerated because it is a high play period. To minimize disruption of play, superintendents often wait until after the Labor Day weekend to initiate conversion. However, competition from annual bluegrass ( $\mathrm{Poa}$ annua sp. Timm.) often disrupts conversion at this time of the year. Up to 460 viable seeds per $\mathrm{kg}$ soil have been found under annual bluegrass turf (Gaussoin and Branham, 1989). Since annual bluegrass seed germination is stimulated in late summer when soil temperatures drop below $21^{\circ} \mathrm{C}$ (Engel, 1967), tremen-

Received for publication 20Feb. 2001. Accepted for publication 9 Oct. 2001. Purdue Univ. Agricultural Experiment Station Journal Paper No. 16310.

${ }^{1}$ Associate Professor

${ }^{2}$ Professional Agronomist. creeping bentgrass.

${ }^{2}$ Purdue Univ. Agronomy Research Center.

${ }^{y}$ Ackerman Hills Golf Course. use in turf in the early 1990s. TE is absorbed primarily in the upper portions of the turf plant with the roots absorbing $5 \%$ or less of the applied TE (Fagerness and Penner, 1998a). Because of this, seeding into an area treated with TE does not inhibit germinating seedlings (Yelverton et al., 1999). Theoretically, TE could be applied prior to overseeding to minimize competition for sunlight from established grass plants and favor the developing seedlings. The objective of our study was to quantify the effect of TE, overseeding date, and overseeding rate on the success of gradually converting perennial ryegrass (Lolium perenne L.) and annual bluegrass/perennial ryegrass/Kentucky bluegrass fairways to creeping bentgrass.

\section{Materials and Methods}

This study was initiated in Sept. 1995 and continued through Aug. 1998 at two sites, the Purdue Univ. Agronomy Research Center (ARC) and the number six fairway of Purdue Univ. Ackerman Hills Golf Course (AHGC). The ARC site was a Chalmers silt loam (fine silty mixed mesic Typic Haplaquoll) with a $\mathrm{pH}$ of 7.0 and $4.7 \%$ organic matter with a stand consisting of $100 \%$ perennial ryegrass. The AHGC site was on a Miami loam (fine loamy mixed mesic Typic Hapludalf) with a $\mathrm{pH}$ of 6.6 and $7.3 \%$ organic matter, and was a mixed stand of consisting of $\approx 70 \%$ annual bluegrass, $20 \%$ perennial ryegrass, and $10 \%$ Kentucky bluegrass. The experimental treatments were in a $3 \times 3 \times 3$ factorial arrangement with three levels of TE $\left(0.0,0.2\right.$, and $\left.0.4 \mathrm{~kg} \cdot \mathrm{ha}^{-1}\right)$, three seeding dates (fall, spring, fall+spring), and three creeping bentgrass seeding rates $(0,49$, and $\left.98 \mathrm{~kg} \cdot \mathrm{ha}^{-1}\right)$. The experiments were arranged in a split plot with seeding date as the main plot and TE and seeding rates as subplots. Subplots were $1.5 \times 1.5 \mathrm{~m}$ with $0.5-\mathrm{m}$ untreated borders. The experiment consisted of three replications of main plots at each site. TE was applied with $\mathrm{CO}_{2}$-powered backpack sprayer with flat fan nozzles $3 \pm 2 \mathrm{~d}$ before seeding in $816 \mathrm{~L} \cdot \mathrm{ha}^{-1}$ water at $207 \mathrm{kPa}$. Table 1 lists dates of TE application and overseeding. Seedbed preparation was done with a $154-\mathrm{cm}$ wide riding aerifier equipped with hollow tines punching 7.5-cm-deep holes, $1.25 \mathrm{~cm}$ in diameter, and on $6.25-\mathrm{cm}$ centers. After drying, cores were dispersed with vertical mowing units on a triplex greensmower set to cut through turf and $0.3 \mathrm{~cm}$ into the underlying soil. There was no measurable thatch layer on

Table 1. Timing of trinexapac-ethyl (TE) applications to a perennial ryegrass stand (ARC ${ }^{z}$ ) or an annual bluegrass, perennial ryegrass, and Kentucky bluegrass fairway $\left(\mathrm{AHGC}^{y}\right)$ prior to overseeding with

\begin{tabular}{lcccccr}
\hline \hline & Fall & Spring & Fall & Spring & Fall & Spring \\
& 1995 & 1996 & 1996 & 1997 & 1997 & 1998 \\
\hline TE application & & & & & & \\
$\quad$ AHGC & 1 Sept. & 25 Apr. & 30 Aug. & 23 Apr. & 25 Aug. & 14 Apr. \\
ARC & 4 Sept. & 26 Apr. & 30 Aug. & 22 Apr. & 25 Aug. & 13 Apr. \\
$\begin{array}{l}\text { Overseeding dates } \\
\text { AHGC }\end{array}$ & & & & & & \\
ARC & 8 Sept. & 1 May & 3 Sept. & 24 Apr. & 26 Aug. & 15 Apr. \\
\hline
\end{tabular}


either site. 'Penneagle' creeping bentgrass was then applied to individual plots with shaker bottles and lightly raked to improve seed to soil contact. Starter fertilizer was applied to main plots immediately after each seeding with $\mathrm{N}$ at $26 \mathrm{~kg} \cdot \mathrm{ha}^{-1}, \mathrm{P}$ at $32 \mathrm{~kg} \cdot \mathrm{ha}^{-1}$, and $\mathrm{K}$ at $43 \mathrm{~kg} \cdot \mathrm{ha}^{-1}$. After seeding, experimental areas received daily irrigation to encourage germination. After germination was noted, irrigation frequency was gradually diminished while irrigation amount was increased, to prevent water stress. Both experimental locations were mowed at $1.9 \mathrm{~cm}$ three times per week with clippings returned. Annual $\mathrm{N}$ fertilization on the ARC site was $37 \mathrm{~kg} \cdot \mathrm{ha}^{-1}$ in May and July, $49 \mathrm{~kg} \cdot \mathrm{ha}^{-1}$ in September, and $73 \mathrm{~kg} \cdot \mathrm{ha}^{-1}$ in November. Fertilization at AHGC was identical to that at ARC, except no $\mathrm{N}$ was applied in July.

Data were recorded monthly from April to November and included percent cover of creeping bentgrass, visual quality, and color. Creeping bentgrass cover was estimated as a percent of each plot by whole-plot visual observation. Visual quality was rated on a 1 to 9 scale with $1=$ dead, 5 = acceptable as a fairway turf, and $9=$ dense fairway turf. Treatments were applied to the same plots for 3 years from Fall 1995 to Spring 1998, and data were recorded through Fall 1998. Analysis of variance (ANOVA) was conducted on all data at the termination of the study using PROC ANOVA (SAS Institute, 1998). Contrasts of interest were calculated on significant effects in the ANOVA. Percent bentgrass cover is reported for the August ratings just prior to subsequent overseeding treatments. Significant differences among locations occurred, thus data were analyzed and presented independently.

\section{Results and Discussion}

$A R C$. Both 49 and $98 \mathrm{~kg} \cdot \mathrm{ha}^{-1}$ seeding rates increased creeping bentgrass cover compared to $0 \mathrm{~kg} \cdot \mathrm{ha}^{-1}$, but there was no advantage to increasing the seeding rate from 49 to 98 $\mathrm{kg} \cdot \mathrm{ha}^{-1}$ at anytime during the study (Table 2). This was expected, as Madison (1966) indicated that though higher seeding rates of creeping bentgrass produced more seedlings shortly after establishment, this effect was short-lived and lower seeding rates produced the same number of seedlings as higher rates after 8 months. There was no advantage of an additional overseeding in spring after a fall overseeding.

Application of TE did not improve establishment of creeping bentgrass in our study (data not shown). It is established that TE will inhibit perennial ryegrass growth for 5 weeks at rates lower than used in our study (Fagerness and Penner, 1998b). However, it appears that any growth reduction of perennial ryegrass due to TE is not enough to favor establishment of creeping bentgrass seedlings. Mefluidide $\{N$-[2,4-dimethyl5 [ [ ( trifluoroethyly l)sulfony l] amino]phenyl]acetatamide $\}$ applied to annual bluegrass prior to overseeding improved the success of overseeding with perennial ryegrass, but not creeping bentgrass (Eggens,

Table 2. Percent creeping bentgrass ${ }^{2}$ in a perennial ryegrass fairway overseeded in fall, spring, and fall+spring at $\mathrm{ARC}^{\mathrm{y}}$ and rated late August of the 3-year study.

\begin{tabular}{lcccc}
\hline Overseeding date & Seed rate & 1996 & 1997 & 1998 \\
\hline Fall & 0 & $0^{\mathrm{x}}$ & 1 & 2 \\
& 49 & 7 & 13 & 22 \\
Spring & 98 & 8 & 18 & 35 \\
& 0 & 0 & 0 & 0 \\
Fall+Spring & 49 & 0 & 1 & 4 \\
& 98 & 0 & 2 & 4 \\
& 0 & 0 & 0 & 1 \\
& 49 & 9 & 21 & 34 \\
\end{tabular}

ANOVA

\begin{tabular}{|c|c|c|c|c|}
\hline Source of variation & df & & lean squ & \\
\hline Block & 2 & $50^{\mathrm{NS}}$ & $556^{\mathrm{NS}}$ & $1541^{\mathrm{NS}}$ \\
\hline Overseeding date (OD) & 2 & $387^{\mathrm{Ns}}$ & $1364^{\mathrm{Ns}}$ & $3365^{\mathrm{Ns}}$ \\
\hline Error a & 4 & 65 & 243 & $688^{\mathrm{Ns}}$ \\
\hline Seed rate (SR) & 2 & $379^{* *}$ & $1517^{* *}$ & $4300^{* *}$ \\
\hline $\mathrm{OD} \times \mathrm{SR}$ & 4 & $110^{*}$ & $347^{*}$ & $887^{* * *}$ \\
\hline Trinexapac-ethyl (TE) & 2 & $20^{\mathrm{Ns}}$ & $40^{\mathrm{NS}}$ & $446^{\mathrm{NS}}$ \\
\hline $\mathrm{OD} \times \mathrm{TE}$ & 4 & $50^{\mathrm{Ns}}$ & $130^{\text {vs }}$ & $270^{\text {vs }}$ \\
\hline $\mathrm{SR} \times \mathrm{TE}$ & 4 & $20^{\text {Ns }}$ & $110^{\text {Ns }}$ & $243^{\mathrm{Ns}}$ \\
\hline $\mathrm{OD} \times \mathrm{SR} \times \mathrm{TE}$ & 8 & $21^{\mathrm{Ns}}$ & $73^{\mathrm{ss}}$ & $89^{\text {Ns }}$ \\
\hline Error b & 48 & 38 & 127 & 222 \\
\hline Contrasts & & & & \\
\hline 0 vs. 49 & 1 & $368^{* *}$ & $1722^{* *}$ & $4835^{* *}$ \\
\hline 0 vs. 98 & 1 & $711^{* *}$ & $2716^{* *}$ & $7728^{* *}$ \\
\hline 49 vs. 98 & 1 & $56^{\mathrm{NS}}$ & $113^{\mathrm{Ns}}$ & $337^{\mathrm{NS}}$ \\
\hline Fall vs. (0 vs. 49$)$ & 1 & $206^{*}$ & $672^{*}$ & $1701^{*}$ \\
\hline Fall vs. (0 vs. 98$)$ & 1 & $288^{* *}$ & $1317^{* *}$ & $4769^{* *}$ \\
\hline Fall vs. (49 vs. 98 ) & 1 & $6^{\mathrm{NS}}$ & $108^{\mathrm{NS}}$ & $773^{\mathrm{NS}}$ \\
\hline Spring vs. (0 vs. 49) & 1 & $0^{\mathrm{NS}}$ & $5^{\mathrm{Ns}}$ & $53^{\mathrm{NS}}$ \\
\hline Spring vs. (0 vs. 98$)$ & 1 & $0^{\text {ss }}$ & $10^{\mathrm{Ns}}$ & $61^{\mathrm{Ns}}$ \\
\hline Spring vs. (49 vs. 98 ) & 1 & $0^{\text {ss }}$ & $1^{\mathrm{Ns}}$ & $1^{\mathrm{Ns}}$ \\
\hline Fall+spring vs. (0 vs. 49 ) & 1 & $346^{* *}$ & $1901^{* *}$ & $5168^{* *}$ \\
\hline Fall+spring vs. (0 vs. 98$)$ & 1 & $841^{* *}$ & $2568^{* *}$ & $5688^{* *}$ \\
\hline Fall+spring vs. (49 vs. 98) & 1 & $107^{\mathrm{Ns}}$ & $50^{\text {Ns }}$ & $12^{\mathrm{Ns}}$ \\
\hline
\end{tabular}

${ }^{2}$ Creeping bentgrass cover was estimated as a percent of each plot.

${ }^{y}$ Purdue Univ. Agronomy Research Center.

${ }^{x}$ Means over three replications and three TE application rates.

Ns, ${ }^{*}, * *$ Nonsignificant or significant at $P=0.05$ or 0.01 , respectively.

1984). Apparently, quicker establishing species like perennial ryegrass may benefit more from a single application of a growth regulator prior to overseeding. Sequential applications of TE following seed germination may be more effective for establishing overseeded creeping bentgrass. This could be true because TE effectively reduces growth of mature perennial ryegrass (Ervin and Koski, 1998; Fagerness and Penner, 1998b), while TE does not affect creeping bentgrass seedlings when applied from 3 weeks before to 3 weeks after planting (Yelverton et al., 1999).

Though overseeding into established annual bluegrass or Kentucky bluegrass turf has been only marginally successful(Eggens, 1979; Gaussoin and Branham, 1989), competition from perennial ryegrass in our study was not sufficient to keep bentgrass from germinating and spreading. One year of overseeding into perennial ryegrass in either the fall or the fall+spring produced up to $14 \%$ bentgrass cover by Aug. 1996, whereas 3 years of treatments produced up to $36 \%$ bentgrass cover. Therefore, with continued overseeding treatments as well as the spread of creeping bentgrass through stoloniferus growth, gradual conversion from a perennial ryegrass fairway to creeping bentgrass over five or more years may be possible. This is significant as golf courses, built in the 1990s with perennial ryegrass fairways, are facing potentially devastating damage from the disease gray leaf spot (Pyricularia grisea) (Harmon et al., 2000; Pederson et al., 2000; Schumann and Jackson, 1999; Uddin et al., 2000) and conversion to creeping bentgrass is highly desirable. Although gradual conversion could be successful, the main disadvantage is that it could take five or more years to complete. During this time, reduced quality must be tolerated if gradual conversion is attempted. Fall and fall+spring overseeding treatments, which produced up to $36 \%$ creeping bentgrass cover by Aug. 1998, also produced the poorest visual quality in our study (data not shown). The poor visual quality was due to nonuniformity with lighter green patches of creeping bentgrass among darker green perennial ryegrass. There is not a herbicide labeled currently herbicide that will selectively control perennial ryegrass in a creeping bentgrass stand and thus this visual inconsistency with the two species may persist for many years. This is a disadvantage to a gradual fairway conversion process.

Visual quality was improved by TE application in May 1996 primarily through creating a denser and darker green turf compared to untreated plots (data not shown), as is consistent with other reports (Ervin and Koski, 1998; Han et al., 1998; Stier et al., 2000). Additionally, mower scalping on this rating date was 
reduced in the TE-treated plots compared to the untreated plots.

$A H G C$. A maximum of three percent creeping bentgrass cover was established at AHGC after the third year of overseeding treatments (Table 3). Even though creeping bentgrass germination was noted on every seeding date, survival of seedlings was very low. This poor establishment was probably due to the competition from annual bluegrass. Annual bluegrass is a bunch-type prolific seed-producing grass and is very competitive with creeping bentgrass (Watschke and Schmidt, 1992). Our results were similar to those of Gaussoin and Branham (1989) and Eggens (1979) where little success was seen with overseeded creeping bentgrass or Kentucky bluegrass into annual bluegrass. Though the creeping bentgrass established in these areas will spread over time, gradual conversion to creeping bentgrass will have limited utility for golf courses with substantial annual bluegrass populations.

Visual quality was improved by spring applications of TE in 1996 compared to the control (data not shown), by suppressing annual bluegrass seedheads as was reported by Fagerness and Penner (1998b). TE improved visual quality over the control in May 1997 due to a slight improvement in color, which has also been reported by others (Han et al., 1998; Stier et al., 2000).

The gradual conversion to creeping bentgrass may be effective on fairways consisting primarily of perennial ryegrass, as long as the superintendent and golfers realize it could take five or more years. Gradual conversion of fairways consisting of primarily Poa annua was unsuccessful given the conditions of our study. Fall overseeding with creeping bentgrass at 49 or $98 \mathrm{~kg} \cdot \mathrm{ha}^{-1}$ was equally effective and additional spring overseeding did not improve overseeding success. Applications of TE prior to overseeding did not enhance establishment, but sequential applications of TE after germination should be investigated.

\section{Literature Cited}

Eggens, J.L. 1984. Fairway overseeding with Embark, p. 17. In: Greensmaster. Thompson Printing Co., Burlington, Ontario.

Eggens,. J.L. 1979. The response of some Kentucky bluegrass cultivars to competitive stress from annual bluegrass. Can. J. Plant Sci. 59:11231128 .

Table 3. Percent creeping bentgrass ${ }^{2}$ in an annual bluegrass, perennial ryegrass, and Kentucky bluegrass fairway overseeded in fall, spring, and fall+spring at $\mathrm{AHGC}^{\mathrm{y}}$ and rated late August of the 3-year study.

\begin{tabular}{lcccc}
\hline Overseeding date & Seed rate & 1996 & 1997 & 1998 \\
\hline Fall & 0 & $0^{\mathrm{x}}$ & 0 & 0 \\
\multirow{3}{*}{ Spring } & 49 & 0 & 0 & 2 \\
& 98 & 0 & 1 & 3 \\
\multirow{3}{*}{ Fall+spring } & 0 & 0 & 0 & 0 \\
& 49 & 0 & 0 & 0 \\
& 98 & 0 & 0 & 1 \\
& 0 & 0 & 0 & 0 \\
& 49 & 1 & 0 & 2 \\
\hline
\end{tabular}

\begin{tabular}{|c|c|c|c|c|}
\hline \multicolumn{5}{|l|}{ ANOVA } \\
\hline$\frac{\text { Source of variation }}{\text { Block }}$ & $\frac{\mathrm{dI}}{2}$ & \multicolumn{2}{|c|}{ Mean square } & $6.2^{\mathrm{Ns}}$ \\
\hline Overseeding date (OD) & 2 & $1.6^{\mathrm{NS}}$ & $0.6^{\mathrm{NS}}$ & $14.3^{\text {vs }}$ \\
\hline Error a & 4 & 1.9 & 0.9 & 18.7 \\
\hline Seed rate (SR) & 2 & $2.0^{\text {Ns }}$ & $0.4^{\mathrm{Ns}}$ & $24.5^{*}$ \\
\hline $\mathrm{OD} \times \mathrm{SR}$ & 4 & $1.5^{\mathrm{Ns}}$ & $0.6^{\mathrm{Ns}}$ & $8.0^{\mathrm{NS}}$ \\
\hline Trinexapac-ethyl (TE) & 2 & $1.1^{\mathrm{Ns}}$ & $0.3^{\mathrm{Ns}}$ & $0.2^{\mathrm{Ns}}$ \\
\hline $\mathrm{OD} \times \mathrm{TE}$ & 4 & $1.5^{\mathrm{Ns}}$ & $0.6^{\mathrm{NS}}$ & $7.7^{\mathrm{vs}}$ \\
\hline $\mathrm{SR} \times \mathrm{TE}$ & 4 & $1.2^{\mathrm{Ns}}$ & $1.0^{\mathrm{Ns}}$ & $0.5^{\mathrm{Ns}}$ \\
\hline $\mathrm{OD} \times \mathrm{SR} \times \mathrm{TE}$ & 8 & $0.9^{\text {ss }}$ & $0.6^{\mathrm{NS}}$ & $3.1^{\mathrm{Ns}}$ \\
\hline Error b & 48 & 1.3 & 0.6 & 6.6 \\
\hline \multicolumn{5}{|l|}{ Contrasts } \\
\hline 0 vs. 49 & 1 & $3.6^{\mathrm{Ns}}$ & $0.7^{\mathrm{Ns}}$ & $34.2^{*}$ \\
\hline 0 vs. 98 & 1 & $0.2^{\mathrm{Ns}}$ & $0.7^{\mathrm{Ns}}$ & $39.2^{*}$ \\
\hline 49 vs. 98 & 1 & $2.2^{\mathrm{Ns}}$ & $0.0^{\mathrm{Ns}}$ & $0.2^{\mathrm{Ns}}$ \\
\hline
\end{tabular}

${ }^{2}$ Creeping bentgrass cover was estimated as a percent of each plot.

${ }^{y}$ Ackerman Hills Golf Course.

${ }^{x}$ Means over three replications and three TE application rates.

Ns, "Nonsignificant or significant at $P=0.05$, respectively.

Engel, R.E. 1967. Temperatures required for germination of annual bluegrass and colonial bentgrass. The Golf Superintendent 35(9):20-23.

Ervin, E.H. and A.J. Koski. 1998. Growth responses of Lolium perenne L. to trinexapac-ethyl. HortScience 33:1200-1202.

Fagerness, M.J. and D. Penner. 1998a. 14Ctrinexapac-ethyl absorption and translocation in Kentucky bluegrass. Crop Sci. 38:1023-1027.

Fagerness, M.J. and D. Penner. 1998b. Evaluation of V-10029 and trinexapac-ethyl for annual bluegrass seedhead suppression and growth regulation of five cool-season turfgrass species. Weed Technol. 12:436-440.

Gaussoin R. and B.E. Branham. 1989. Influence of cultural factors on species dominance in a mixed stand of annual bluegrass/creeping bentgrass. Crop Sci. 29:480-484.

Han, S.W., T.W. Fermanian, J.A. Juvik, and L.A. Spomer. 1998. Growth retardant effects on visual quality and nonstructural carbohydrates of creeping bentgrass. HortScience 33:1197-1199.

Harmon, P., K. Rane, G. Ruhl, and R. Latin. 2000. First report of gray leaf spot on perennial ryegrass in Indiana. Plant Dis. 84(4):492.
Madison, J.H. 1966. Optimum rates of seeding turfgrasses. Agron. J. 58:441-443.

Pedersen, D.K., R.T. Kane, and H.T. Wilkinson. 2000. First report of gray leaf spot caused by Pyricularia grisea in Lolium perenne in Illinois. Plant Dis. 84(10): 1151.

Schumann, G.L. and N. Jackson. 1999. First report of gray leaf spot (Pyricularia grisea) on perennial ryegrass (Lolium perenne) in New England. Plant Dis. 83(11):1073.

Stier, J., Z. Reicher, and G. Hardebeck. 2000. Effect of the growth regulator Proxy on creeping bentgrass fairway turf. J. Environ. Hort. 18:53-58.

Watshke, T.L. and R.E. Schmidt. 1992. Ecological aspects of turf communities, p. 129-174. In: D.V. Waddington, R.N. Carrow, and R.C. Shearman (eds.). Turfgrass Amer. Soc. Agron., Crop Sci. Soc. Amer., Soil Sci. Soc. Amer., Madison, Wis.

Uddin, W., M.D. Soika, F.E. Moorman, and G. Viji. 1999. A serious outbreak of blast disease (gray leaf spot) of perennial ryegrass in golf course fairways in Pennsylvania. Plant Dis. 83(8):783. Yelverton, F.H., J. Isgrigg, III, and J. Hinton. 1999. Proc. Southern Weed Sci. Soc. 52:72. 